\title{
Analisis Pengaruh Beta, Leverage, Dividend Payout Ratio, dan Earnings Persistence terhadap Earnings Response Coefficient pada Indeks Kompas 100
}

\author{
Dwi Husiano ${ }^{1}$, Suratno ${ }^{2}$ \\ ${ }^{1}$ Universitas Pancasila, Jl. Srengseng Sawah, Jagakarsa, Jakarta Selatan 12640 \\ ${ }^{2}$ Universitas Esa Unggul, Jalan Arjuna Utara No.9, Kebon Jeruk - Jakarta Barat 11510
}

\section{N F O A R T I K E L}

\author{
JEL Classification: \\ G14 \\ G30
}

Keywords:

earnings response coefficient,

leverage, systematic risk, earnings persistence, growth opportunities, dividend payout ratio.

\begin{abstract}
A B S T R A C T
Earnings response coefficient (ERC) reflects the strength of the relationship between income with stock prices. This study aimed to analyze the determinants of the ERC. The population was 100 companies included in the Kompas 100 Index. Tests carried out by multiple regression test. The results show that the leverage, dividend payout ratio affects the ERC, while systematic risk and growth opportunities not significant effect on the ERC. The results are expected to contribute to the issuer, that the consideration of investors to invest in the stock market especially Kompas 100 Index shown to be affected by the level of risk and ividend payout ratio.
\end{abstract}

\begin{abstract}
A B S T RA K
Earnings response coefficient (ERC) mencerminkan kekuatan hubungan antara laba dengan harga saham. Penelitian ini bertujuan untuk menganalisis faktor-faktor penentu ERC. Populasi adalah 100 perusahaan yang masuk dalam Indeks Kompas 100. Pengujian dilakukan dengan uji regresi berganda. Hasil pengujian menunjukkan bahwa leverage, dividend payout ratio berpengaruh terhadap ERC, sementara systematic risk dan growth opportunities berpengaruh tidak signifikan terhadap ERC. Hasil penelitian diharapkan yang dapat memberikan kontribusi kepada emiten, bahwa pertimbangan investor untuk berinvestasi di pasar modal khususnya saham yang Indeks Kompas 100 terbukti dipengaruhi oleh tingkat resiko dan rasio pembayaran deviden.
\end{abstract}

\section{Pendahuluan}

Laba merupakan informasi utama yang dipercayai mampu memengaruhi investor untuk membuat keputusan membeli, menjual, atau menahan sekuritas yang diterbitkan oleh perusahaan (Diantimala, 2008). Hal ini dapat dibuktikan dengan memerhatikan hubungan laba akuntansi dan tingkat pengembalian (return) ketika menggunakan laba akuntansi untuk menilai saham perusahaan (Suaryana, 2008).

Walaupun informasi laba merupakan hal yang paling direspon oleh investor karena memberikan gambaran mengenai kinerja perusahaan, namun informasi laba saja kadang tidak cukup untuk dijadikan sebagai dasar pengambilan keputusan investor karena ada kemungkinan informasi tersebut bias. Biasnya

*Email Korespondensi: 'dhmangindaan@gmail.com, 2soeratno_54@yahoo.com 
informasi laba antara lain disebabkan oleh penyampaian laporan keuangan yang tidak tepat waktu dan adanya praktek manajemen laba serta ketidakcukupan informasi yang diungkapkan dalam laporan keuangan (Etty, 2008). Laba memiliki keterbatasan yang dipengaruhi oleh asumsi perhitungan sehingga dibutuhkan informasi lain untuk memprediksi return saham perusahaan. Respon pemegang saham akan lebih besar terhadap pertumbuhan laba positif karena asumsi laba akan memicu kenaikan harga pasar saham. Dalam beberapa situasi terjadi sebaliknya, saham AALI, LSIP, dan MEDC pada tahun 2008 mengalami penurunan harga ketika perusahaan mencatat pertumbuhan laba positif. Sebaliknya pada tahun berikutnya harga saham mengalami kenaikan ketika perusahaan mengalami pertumbuhan laba negatif. Saham INDF, dan LSIP pun mengalami hal yang sama pada tahun 2011, dan 2012.

Earnings response coefficient (ERC) merupakan besarnya koefisien slope dalam regresi yang menghubungkan laba sebagai salah satu variabel bebas dan return saham sebagai variabel terikat (Palupi, 2006). Dengan kata lain, ERC merupakan respon pasar yang terkandung dalam harga saham (cumulative abnormal return) atas perubahan yang terjadi pada laba (Unexpected Earnings).

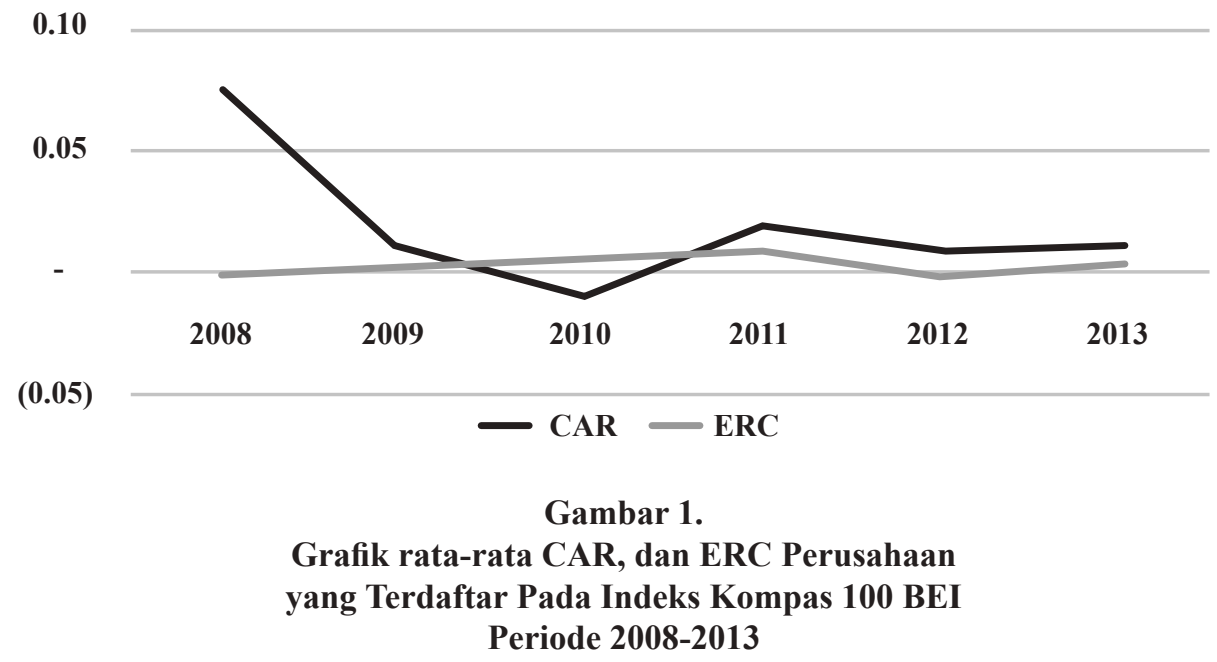

Gambar 1 menunjukkan bahwa gap terbesar antara CAR (0.08) dan ERC (0.007) terjadi pada tahun 2008 , hal ini menandakan bahwa informasi laba tidak secara signifikan direspon oleh pasar yang lebih cenderung menunggu efek rebound pasca krisis global. Respon pasar terhadap pengumuman laba dan persistensi laba tertinggi terjadi pada tahun 2011 dengan nilai ERC sebesar 0,0241, dan EP $(1,56)$, setelah periode sebelumnya mencatatkan CAR terendah (-0.008). Pada tahun 2012, informasi laba tidak mencerminkan kualitas laba yang ditunjukkan dengan nilai ERC negatif (-0.0012). Nilai tersebut menunjukkan respon pasar yang terkandung dalam harga saham (abnormal return) berbanding terbalik atas perubahan yang terjadi pada laba (unexpected earnings), meskipun rata-rata pertumbuhan laba positif (42\%). Pada tahun 2013, ditandai dengan pengurangan stimulus oleh bank sentral Amerika Serikat (The Fed) mengakibatkan terdepresiasinya nilai tukar mata uang regional, termasuk rupiah. Hal tersebut berdampak pada penurunan rata-rata pertumbuhan laba $(-22 \%)$, perubahan harga saham (-9\%), return ekspektasi $(-0,002)$, dan tingkat resiko (beta) (1.04) yang berada pada nilai terendah dibandingkan periode sebelumnya. Sedangkan rata-rata CAR $(0,013)$, dan ERC (0.0035) lebih tinggi dibandingkan periode sebelumnya.

Asumsi yang mendasari penelitian ini adalah bahwa investor memberikan respon berbeda terhadap masing-masing informasi laba akuntansi sesuai dengan kualitas informasi laba tersebut. Semakin berkualitas laba akuntansi maka semakin tinggi respon investor. Kualitas laba tidak berhubungan dengan tinggi atau rendahnya laba yang dilaporkan, menurut Siegel (1990) dalam Adharini (2005) kualitas laba meliputi understatement dan overstatement dari laba (bersih), stabilitas komponen dalam laporan rugi laba, realisasi resiko asset, pemeliharaan atas modal, dan dapat merupakan prediktor laba masa depan (predictive value). Earnings response coefficient (ERC) merupakan proksi dari kualitas laba. Lev dan Zarowin (1999) 
menggunakan earnings response coefficient (ERC) sebagai alternatif untuk mengukur value relevance informasi laba. Rendahnya ERC menunjukan bahwa laba kurang informatif bagi investor untuk membuat suatu keputusan ekonomi.

Sri Mulyani, Nur F. Asyik, Andayani (2007) meneliti faktor-faktor yang mempengaruhi ERC pada perusahaan yang terdapat di Bursa Efek Jakarta. Dengan menggunakan beberapa faktor yang dihubungkan dengan ERC pada penelitian tersebut meneliti hubungan atau pengaruh persistensi laba, struktur modal, beta atau resiko, kesempatan bertumbuh, dan ukuran perusahaan terhadap ERC. Hasil penelitian menyimpulkan bahwa persistensi laba dan struktur modal berpengaruh secara signifikan terhadap ERC, beta dan kesempatan bertumbuh berpengaruh terhadap ERC, Semakin besar ukuran perusahaan akan mempunyai informasi yang lebih dari perusahaan kecil, kualitas auditor tidak mempengaruhi reaksi pasar.

Penelitian lainnya mengenai faktorfaktor yang mempengaruhi ERC dilakukan oleh A. Zubaidi Indra, Agus Zahron, Ana Rosianawati (2008). Dari empat faktor yang dapat mempengaruhi kualitas laba hanya beta dan market to book value ratio yang memiliki pengaruh signifikan terhadap resiko kualitas laba, sedangkan variabel lainnya, yaitu leverage dan size tidak berpengaruh secara signifikan terhadap kualitas laba, tetapi secara empiris, terdapat pengaruh yang signifikan antara variabel independen levarage, beta, market book value ratio, serta firm size secara bersama-sama terhadap ERC pada perusahaan properti dan real estate yang terdaftar di Bursa Efek Indonesia pada tahun 2004-2008.

Berdasarkan latar belakang di atas maka penulis tertarik untuk menganalisis kembali faktor-faktor yang berhubungan dengan ERC. Perbedaan dari penelitian sebelumnya disamping faktor beta, leverage, dan earnings persistence, dalam penelitian ini juga melibatkan faktor devidend payout ratio yang belum dilakukan oleh peneliti sebelumnya. Pada penelitian terdahulu beberapa variabel yang diuji memberikan hasil berbeda. Dengan asumsi konteks, waktu penelitian dan objek atau sample yang diteliti berbeda maka penelitian dapat menghasilkan kesimpulan yang berbeda pula.

Berdasarkan uraian yang telah disajikan di atas maka rumusan masalah penelitian adalah "Bagaimana pengaruh beta, leverage, dividend payout ratio, dan earnings persistence secara simultan dan parsial terhadap earnings response coefficient (ERC)?"

Tujuan dari penelitian ini adalah untuk mengetahui seberapa besar pengaruh beta, leverage, dividend payout ratio, dan earnings persistence, baik secara simultan maupun parsial, terhadap earnings response coefficient (ERC).

\section{Telaah Teori dan Pengembangan Hipotesis}

\subsection{Signaling Theory}

Signaling Theory dalam penelitian ini menjelaskan bahwa manajemen perusahaan sebagai pihak yang memberikan sinyal berupa informasi laba dalam laporan keuangan perusahaan. Teori sinyal menyatakan bahwa perusahaan yang berkualitas baik dengan sengaja akan memberikan sinyal pada pasar dalam bentuk informasi, dengan demikian pasar diharapkan dapat membedakan perusahaan yang berkualitas baik dan buruk. Jika pengumuman laba tersebut sebagai sinyal baik (good news) bagi investor, yaitu kenaikan laba perusahaan, maka reaksi yang ditimbulkan terhadap harga saham adalah kenaikan harga saham, dan demikian pula sebaliknya. Teori signaling menyatakan bahwa perusahaan yang berkualitas baik dengan sengaja akan memberikan sinyal pada pasar yang berupa informasi, dengan demikian pasar diharapkan dapat membedakan perusahaan yang berkualitas baik dan buruk. Agar sinyal tersebut efektif, maka harus dapat ditangkap pasar dan dipersepsikan baik, serta tidak mudah ditiru oleh perusahaan yang berkualitas buruk (Megginson, 1987 dalam Ansori, 2010).

Informasi yang lengkap, relevan, akurat, dan tepat waktu sangat dibutuhkan oleh investor di pasar modal sebagai alat analisis untuk mengambil keputusan investasi (Jogiyanto, 2010). Rasio-rasio dari laporan keuangan seperti Current Ratio, Debt to Equity Ratio, Return On Asset, maupun rasio-rasio lain akan sangat bermanfaat bagi investor mupun calon investor sebagai salah satu dasar analisis dalam berinvestasi. Teori signaling menjelaskan bahwa perusahaan melaporkan secara suka rela ke pasar modal agar investor mau menginvestasikan dananya, kemudian manajer akan memberikan sinyal dengan 
menyajikan laporan keuangan dengan baik agar nilai saham meningkat (Desi Arista, 2012).

\section{$2.2 \quad$ Efficient Market Hypothesis}

Fama (1970) dalam Cheng dan Nasir (2010) mengemukakan bahwa suatu pasar dikatakan efisien apabila tidak seorangpun, baik investor individu maupun investor institusi, akan mampu memperoleh return tidak normal (abnormal return), setelah disesuaikan dengan risiko, dengan menggunakan strategi perdagangan yang ada. Teori hipotesis pasar setengah kuat melandasi tentang value relevance informasi laba (pengaruh pengumuman laba terhadap reaksi investor) bahwa laba memiliki nilai relevansi yang diketahui dari pengaruhnya terhadap reaksi investor yang digambarkan dalam harga saham. Semakin besar laba maka reaksi invetor akan semakin tinggi. untuk mengukur value relevance informasi laba atau untuk mengetahui hubungan laba terhadap retur saham dapat diukur menggunakan earnings response coefficient (ERC).

Beaver (1986) dalam Gumanti (2002) mendefinisikan pasar efisien ditinjau berdasarkan distribusi informasi. Harga merupakan cermin dari adanya pemahaman menyeluruh (universal) atas suatu informasi, sehingga jika harga memiliki kandungan informasi, maka dikatakan bahwa harga yang terbentuk sepenuhnya mencerminkan sistem informasi. Informasi yang diyakini dapat mencerminkan harga akan menjadi sorotan banyak pihak yang berkepentingan di pasar modal. Pihak-pihak dimaksud antara lain adalah pembuat kebijakan (pemerintah, badan pengawas pasar modal atau asosiasi penentu kebijakan akuntansi), manajemen perusahaan sebagai pembuat laporan keuangan, akuntan (auditor) sebagai pihak yang memberikan sertifikasi, dan perantara informasi, seperti pelanggan dan pesaing, serta investor.

\subsection{Reaksi Pasar}

Tujuan studi peristiwa dalam penelitian ini adalah untuk mengukur hubungan antara pengumuman laba dengan reaksi pasar, dengan asumsi bahwa informasi tersebut dapat mempengaruhi perubahan harga saham atau besarnya volume perdagangan saham. Studi peristiwainijugaseringdisebutdenganpengujian kandungan informasi. Jika pengumuman mengandung informasi maka diharapkan pasar akan bereaksi pada waktu pengumuman tersebut diterima oleh pasar. Reaksi tersebut ditunjukkan dengan adanya perubahan harga sekuritas yang bersangkutan (Mulyani et al., 2007). Subekti (2005) mengungkapkan bahwa untuk mengukur adanya reaksi pasar dapat menggunakan variabel abnormal return dan volume perdagangan saham.

\subsection{Earnings Response Coefficient}

Scott (2000), Cho and Jung (1991) dalam Etty (2008) menyatakan bahwa earnings response coefficient (ERC) mengukur seberapa besar return saham dalam merespon angka laba yang dilaporkan oleh perusahaan yang mengeluarkan sekuritas tersebut. Dengan kata lain ERC adalah reaksi atas laba yang diumumkan (published) oleh perusahaan. Reaksi ini mencerminkan kualitas dari laba yang dilaporkan perusahaan. Dan tinggi rendahnya ERC sangat ditentukan kekuatan responsif yang tercermin dari informasi (good/ bad news) yang terkandung dalam laba. ERC merupakan salah satu ukuran atau proksi yang digunakan untuk mengukur kualitas laba (Collins et. al., 1984 dalam Etty, 2008).

Cho dan Jung (1991) dalam Etty (2008) mengklasifikasi pendekatan teoritis ERC menjadi dua kelompok, yaitu: (1) model penilaian yang didasarkan pada informasi ekonomi (information economics based valuation model) seperti dikembangkan oleh Holthausen dan Verrechia (1988) dan Lev (1989) dalam Etty (2008) yang menunjukkan bahwa kekuatan respon investor terhadap sinyal informasi laba merupakan fungsi dari ketidakpastian di masa mendatang. Semakin besar noise dalam sistem pelaporan perusahaan (semakin rendah kualitas laba) maka semakin kecil ERC); dan (2) model penilaian yang didasarkan pada time series laba (time series based valuation model) seperti dikembangkan oleh Beaver, Lambert dan Morse (1980).

\subsection{Rerangka Pemikiran Teoritis}

\section{Pengaruh Risiko Sistematik (Beta) Terhadap Earnings Response Coefficient}

Investor akan mengurangi tingkat risiko yang diterimanya dengan mempertimbangkan risiko spesifik suatu perusahaan dalam pengambilan keputusan investasinya. Sensitivitas investor terhadap informasi mengenai perusahaan berisiko kecil akan 
lebih besar karena perusahaan dengan risiko lebih kecil lebih dipercaya (Palupi, 2006). Penelitian Mulyani et al. (2007) menunjukkan bahwa risiko sistematik berhubungan negatif dengan ERC. Sejalan dengan penelitian yang dilakukan Collins dan Kothari (1989) bahwa risiko (riskness) yang menunjukkan variasi antar perusahaan, dan risk-free interest rate yang menunjukkan variasi antar waktu terbukti secara empiris berpengaruh negatif signifikan dengan earnings response coefficient.

H1: Terdapat pengaruh negatif beta terhadap earnings response coefficient (ERC).

\section{Pengaruh Leverage Terhadap Earnings Response Coefficient}

Perusahaan dengan tingkat leverage yang tinggi berarti memiliki utang yang lebih besar dibandingkan modal. Dengan demikian jika terjadi peningkatan laba maka yang diuntungkan adalah debtholders, karena debitor mempunyai keyakinan bahwa perusahaan akan mampu melakukan pembayaran atas hutang. Namun haliniakan direspon negatifoleh investor karena investor akan beranggapan bahwa perusahan akan lebih menguntungkan kreditur karena lebih mengutamakan pembayaran hutang daripada pembayaran dividen. sehingga semakin baik kondisi laba perusahaan maka semakin negatif respon pemegang saham. Hasil pengujian yang dilakukan oleh Mulyani et al. (2007) menunjukkan bahwa leverage keuangan berpengaruh secara signifikan terhadap earnings response coefficient (ERC). Temuan studi ini konsisten dengan Dhaliwal et al. (1991) dan Etty Murwaningsari (2008)

H2: Terdapat pengaruh negatif leverage terhadap earnings response coefficient (ERC).

\section{Pengaruh Dividend Payout Ratio Terhadap Earnings Response Coefficient}

Jensen (1986) memprediksi bahwa harga saham akan meningkat jika perusahaan membayar atau berjanji untuk membayar kelebihan kas (deviden) kepada pemegang saham. Sebaliknya, harga saham akan turun jika perusahaan tidak membagikan atau menginvestasi kembali kelebihan kas tersebut. Brickely (1983) menunjukkan bahwa harga saham biasa terlihat menguntungkan (favorable) ketika perusahaan meningkatkan dividen. Lang dan Litzenberger dalam Voght dan $\mathrm{Vu}$ (2000) menunjukkan bahwa reaksi harga saham perusahaan-perusahaan yang mempunyai peluang investasi rendah (poor investment opportunities) berasosiasi positif dengan peningkatan dividen. Kallapur (1994) menguji apakah perusahaan-perusahaan besar (large) dan mapan (mature) yang terdaftar di NYSE juga merasakan dampak dari masalah-masalah aliran kas bebas. Temuan ini menujukkan bahwa reaksi harga saham yang diukur dengan ERC berhubungan positif dengan rasio pembayaran dividen.

H3: Terdapat pengaruh positif antara dividend payout ratio (DPR) terhadap earnings response coefficient (ERC).

\section{Pengaruh Earnings Persistence Terhadap Earnings Response Coefficient}

Persistensi laba sering digunakan sebagai pertimbangan kualitas laba karena persistensi laba merupakan komponen dari karakteristik kualitatif relevansi yaitu predictive value (Jonas dan Blanchet, 2000). Predictive value adalah salah satu komponen relevansi selain feedback value dan timeliness. Mulyani et al. (2007) menyimpulkan bahwa persistensi laba memberikan pengaruh positif terhadap ERC, artinya semakin permanen perubahan laba (persistensi laba tinggi) dari waktu ke waktu maka semakin tinggi ERC, hal ini berkaitan dengan kekuatan laba. Hasil penelitian tersebut konsisten dengan penelitian yang dilakukan oleh Kormendi dan Lipe (1987), Easton dan Zmijweski (1989), Chandrarin (2003), Setiati dan Kusuma (2004), Mayangsari (2004), Jaswadi (2004), Palupi (2006), dan Jang et al. (2007).

H4: Terdapat pengaruh positif earnings persistence terhadap earnings response coefficient (ERC).

\section{Pengaruh Beta, Leverage, Dividend Payout Ratio, dan Earnings Persistence Secara Simultan Terhadap Earnings Response Coefficient}

H5: Terdapat pengaruh beta, leverage, dividend payout ratio, dan earnings persistence secara simultan terhadap earnings response coefficient (ERC). 


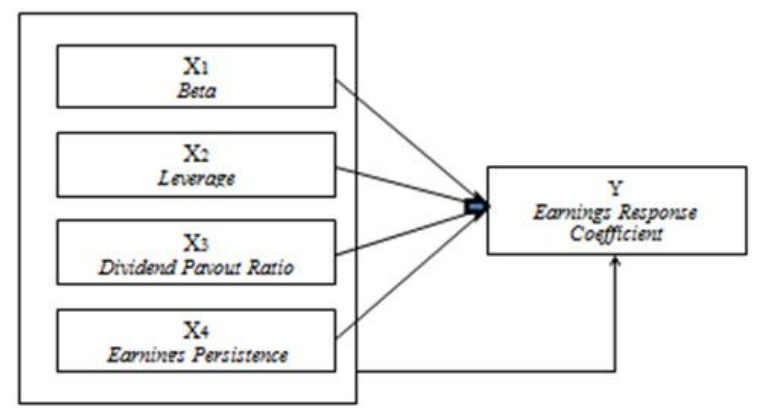

Gambar 2.

Rerangka Pemikiran Teoritis

\section{Metode Penelitian}

Penelitian ini menggunakan data kuantitatif, dan merupakan data sekunder. Data sekunder yang digunagan berasal dari laporan keuangan tahunan dan harga saham perusahaan yang terdaftar pada indeks Kompas 100 Bursa Efek Indonesia (BEI). Adapun periode penelitian ini mencakup waktu lima tahun yakni tahun 2008 s.d. 2013. Data penelitian ini diperoleh secara tidak langsung melalui media perantara, yakni literatur Pusat Referensi Pasar Modal Bursa Efek Indonesia, Indonesian Capital Market Library (ICaMEL), Indonesian Capital Market Directory (ICMD), dan situs BEI (www.idx.co.id).

Populasi yang digunakan dalam penelitian ini adalah perusahaan go public yang terdaftar pada indeks Kompas 100 di Bursa Efek Indonesia (BEI). Sementara sampelnya adalah perusahaan yang terdaftar pada indeks Kompas 100 di BEI selama periode penelitian yang meliputi jangka waktu 5 tahun (20082013).

Pengambilan sampel menggunakan teknik purposive sampling atau penilaian (judgment). Teknik pemilihan sampel dilakukan dengan cara purposive sampling method, yaitu tipe pemilihan sampel secara tidak acak yang informasinya diperoleh dengan pertimbangan atau kriteria tertentu (Indriantoro, dan Supomo, 1999) dengan tujuan untuk melihat pengaruh ke lima variabel terhadap emiten yang terdaftar pada indeks Kompas 100 BEI.

\subsection{Definisi Operasional Variabel}

\section{Variabel Dependen (Y)}

Variabel dependen (variabel tidak bebas), yaitu variabel yang dipengaruhi oleh variabel independen. Variabel dependen dalam penelitian ini adalah earnings response coefficient (ERC). Besarnya ERC diperoleh dengan melakukan beberapa tahap perhitungan berikut ini :

\section{Cumulative Abnormal Return (CAR)}

Cumulative abnormal return (CAR) merupakan akumulasi abnormal return selama periode peristiwa untuk masingmasing saham (Norpratiwi, 2003). Mulyani, et al. (2007) mendefinisikan CAR sebagai proksi dari harga saham atau reaksi pasar. Pada penelitian ini akumulasi abnormal return dalam jendela pengamatan selama 7 (tujuh) hari, yaitu 3 (tiga) hari sebelum, 1 (satu) hari peristiwa, dan 3 (tiga) hari setelah publikasi laporan keuangan.

2. Unexpected Earnings (UE)

Unexpected earnings adalah perbedaan laba per lembar saham pada periode penelitian dengan laba per lembar saham pada periode sebelumnya, diukur menggunakan pengukuran Suaryana (2004)

3. Earnings Response Coefficient (ERC)

ERC merupakan koefisien yang diperoleh dari regresi antara proksi harga saham dan laba akuntansi. Proksi harga saham yang digunakan adalah CAR, sedangkan proksi laba akuntansi adalah UE.

\section{Variabel Independen}

Variabel independen (variabel bebas) adalah variabel yang mempengaruhi variabel terikat. Sehubungan dengan hipotesis di atas maka variabel independen dalam penelitian ini adalah beta, leverage, dividend payout ratio, dan earnings persistence. Definisi operasional dalam penelitian ini adalah sebagai berikut:

1. Risiko sistematik (Beta) (X1)

Beta adalah variabilitas dari return saham atau portofolio yang berhubungan dengan perubahan return pasar secara keseluruhan (Horne, 1989). Risiko diukur menggunakan risiko sistematik (beta) dengan menggunakan market model (Jogiyanto, 2010) dengan mengunakan pendekatan single index model.

2. Leverage (X2)

Variabel ini menggunakan proksi debt assets ratio (DAR), yaitu rasio perbandingan total debt terhadap total asset. (Dhaliwal et al., 1991).

3. Dividend Payout Ratio (X3)

Dividend payout ratio merupakan perbandingan antara dividend per share 
dengan earnings per share (Ang, 1997).

4. Earnings Persistence (X4)

Earnings persistence adalah revisi dalam laba akuntansi yang diharapkan di masa depan (expected future earnings) yang diimplikasi oleh laba akuntansi tahun berjalan (current earnings) (Pennman, 1992). Pada penelitian ini diukur dengan slope regresi atas perbedaan laba saat ini dengan laba sebelumnya (Chandarin, 2003).

Tabel. 1.

Definisi Operasional Variabel

\begin{tabular}{|c|c|c|c|c|}
\hline Variabel & Sub Var. & Indikator & Skala & Referensi \\
\hline $\begin{array}{l}\text { 1. Earnings } \\
\text { Response } \\
\text { Coefficient } \\
\text { (ERC) } \\
\text { (Y) } \\
\mathrm{CAR}_{\mathrm{it}}=\alpha_{0} \\
+\alpha_{1} \mathrm{UE}_{\mathrm{it}}+ \\
\varepsilon_{\mathrm{it}}\end{array}$ & CAR & $\begin{array}{l}\text { - Abnormal return sekuritas ke- } i \text { pada } \\
\text { periode peristiwa ke } t \\
\text { - } \text { Return saham ke- } i \text { pada periodeperistiwa } \\
\text { ke } t \\
\text { - } \text { Return ekspektasi sekuritas ke-i pada } \\
\text { periode peristiwa ke } t \\
C A R_{i, t}[t 1-t 2]=\sum A R_{i t-t 1} \\
\text { - } \text { Unexpected earnings perusahaan } i \text { pada } \\
\text { periode (tahun) } t \\
\text { - Laba akuntansi perusahaan } i \text { pada } \\
\text { periode (tahun) } t \\
\text { - Laba akuntansi perusahaan } i \text { pada } \\
\text { periode (tahun) sebelumnya }(t-1) \\
U E_{i t}=\frac{\left(E_{i t}-E_{i t}-1\right)}{E_{i t}-1}\end{array}$ & Rasio & $\begin{array}{l}\text { Brown dan } \\
\text { Warner (1985), } \\
\text { Suaryana (2004) }\end{array}$ \\
\hline $\begin{array}{l}\text { 2. Resiko } \\
\text { sistematik } \\
(\text { Beta })\left(\mathrm{X}_{1}\right)\end{array}$ & Beta & $\begin{array}{l}\text { - Return perusahaan } i \text { pada periode } t \\
\text { - } \text { Beta yang merupakan koefisein } \\
\text { yang mengukur perubahan } \mathrm{R} i \text { akibat } \\
\text { perubahan } \mathrm{R} m \\
\text { - } \text { Return pasar pada periode } \mathrm{t} \\
\mathrm{R}_{\mathrm{it}}=\alpha_{\mathrm{i}}+\beta_{\mathrm{it}} \mathrm{R}_{\mathrm{mt}}+\varepsilon_{\mathrm{it}}\end{array}$ & Rasio & Hartono (2003) \\
\hline $\begin{array}{l}\text { 3. Leverage } \\
\left(\mathrm{X}_{2}\right)\end{array}$ & DAR & $\begin{array}{l}\text { - Total hutang perusahaan i pada periode } \mathrm{t} \\
\text { - Total aset perusahaan i pada periode } \mathrm{t} \\
D A R_{i t}=\frac{T D_{i t}}{T A_{i t}}\end{array}$ & Rasio & Dhaliwal (1991) \\
\hline $\begin{array}{l}\text { 4. Dividend } \\
\text { Payout } \\
\text { Ratio }\left(\mathrm{X}_{3}\right)\end{array}$ & DPR & $\begin{array}{l}\text { - Dividend per share perusahaan i pada } \\
\text { periode } \mathrm{t} \\
\text { - Earnings per share perusahaan i pada } \\
\text { periode } \mathrm{t} \\
D P R_{i t}=\frac{D P S_{i t}}{E P S_{i t}}\end{array}$ & Rasio & $\begin{array}{l}\text { Baskin (1989), } \\
\text { Ang (1997), } \\
\text { Yuniningsih } \\
\text { (2002) }\end{array}$ \\
\hline $\begin{array}{l}\text { 5. Earnings } \\
\text { Persistence } \\
\left(\mathrm{X}_{4}\right)\end{array}$ & EP & $\begin{array}{l}\text { Earnings perusahaan i pada periode } \mathrm{t} \\
\text { - Earnings perusahan i pada periode } \mathrm{t}-1 \\
\mathrm{X}_{\mathrm{it}}=\alpha+\beta \mathrm{X}_{\mathrm{it}-1}+\varepsilon_{\mathrm{it}}\end{array}$ & Rasio & $\begin{array}{l}\text { Chandradin } \\
\text { (2003) }\end{array}$ \\
\hline
\end{tabular}


Metode yang dipakai dalam menganalisis variabel-variabel dalam penelitian ini adalah menggunakan regresi linier berganda. Analisis regresi linear berganda digunakan untuk mengetahui atau memperoleh gambaran mengenai pengaruh variabel independen pada variabel dependen dan bertujuan untuk mengestimasi dan atau memprediksi rata-rata populasi atau nilai rata-rata variabel dependen berdasarkan nilai variabel independen yang diketahui (Ghozali, 2013).

Model yang digunakan dalam penelitian ini adalah:

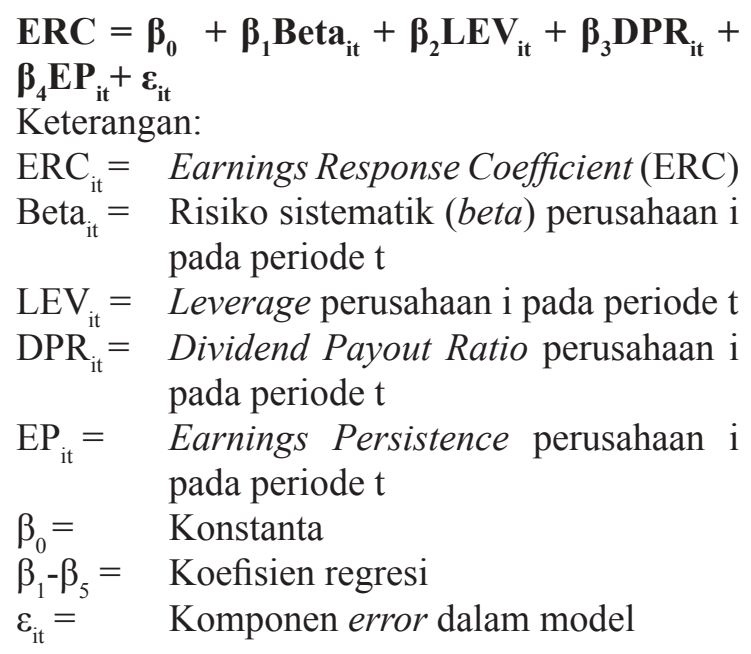

\section{Uji Asumsi Klasik}

1. Uji Normalitas

Uji normalitas digunakan untuk mengetahui apakah dalam suatu model regresi, baik variabel dependen dan variabel independen memiliki residual yang distribusi normal. Uji normalitas dalam penelitian ini dilakukan dengan menggunakan uji One Sample Kolmogorov-Smirnov Test dengan melihat angka signifikansi dan plot probabilitas normal. Apabila nilainya lebih besar daripada level signifikasi penelitian (0.05), maka tidak terjadi masalah normalitas.

2. Uji Multikolinearitas

Menurut Imam Ghozali (2013) uji multikolinearitasadalahujiuntukmengetahui hubungan yang bermakna korelasi (langsung) antara setiap variabel independen dalam suatu regresi. Model regresi yang baik seharusnya tidak terjadi korelasi di antara variabel independen. Pengujian ini dapat dilakukan dengan menggunakan Variance Inflation Factor (VIF). Jika nilai VIF > 10, maka variabel tersebut mempunyai persoalan multikolinearitas dengan variabel independen.

3. Uji Autokorelasi

Autokorelasi adalah keadaan dimana variabel gangguan pada periode tertentu berkorelasi dengan variabel lain, dengan kata lain variabel gangguan tidak random. Untuk menguji apakah hasil-hasil estimasi model regresi tersebut tidak mengandung korelasi serial diantara disturbance termnya, maka dipergunakan Durbin Watson Statistik (koefisien korelasi Durbin Watson).

\begin{tabular}{|c|c|c|c|c|}
\hline $\begin{array}{l}\text { Tolak } \mathrm{H}_{0} \text {, } \\
\text { berarti ada } \\
\text { autokorelasi } \\
\text { positif }\end{array}$ & 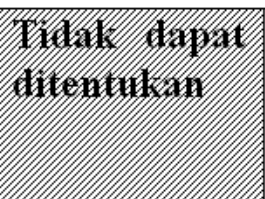 & $\begin{array}{l}\text { Tidak menolak } \mathrm{H}_{0} \text {, } \\
\text { berarti tidak ada } \\
\text { autokorelasi }\end{array}$ & (1) & $\begin{array}{l}\text { Tolak } \mathrm{H}_{0}, \\
\text { berarti ada } \\
\text { autokorelasi } \\
\text { negative }\end{array}$ \\
\hline & & 2 & du & \\
\hline
\end{tabular}

Gambar 2.

Indikator Autokorelasi dengan Uji Durbin Watson

4. Uji Heteroskedastisitas

Heteroskedastisitas adalah adanya varians yang berbeda yang dapat membiaskan hasil yang telah dihitung. Untuk mendeteksi ada atau tidaknya gejala heteroskedastisitas, dapat dilakukan dengan beberapa cara, salah satunya adalah melalui metode visual yaitu dengan melihat penyebaran nilai-nilai residual terhadap nilai-nilai prediksi. Jika penyebarannya tidak membentuk suatu pola tertentu seperti meningkat atau menurun, maka model regresi layak dipakai untuk memprediksi. Harga Saham berdasarkan masukan variabel bebas. 


\subsection{Teknik Pengujian Hipotesis}

1. Koefisien Korelasi (R), $R$ Square, dan Adjusted R Square

Menghitung koefisien korelasi (R), koefisien determinan ( $R$ Square) dan adjusted $R$ Square. Adjusted R Square digunakan untuk mengukur seberapa besar nilai seluruh variabel independen dapat menjelaskan variabel dependen (biasanya digunakan dalam pengujian regresi linear berganda). Dapat disimpulkan bahwa bagus atau tidaknya suatu model bukanlah ditentukan oleh $\mathrm{R}^{2}$ yang tinggi, namun harus lebih memperhatikan relevansi logis atau teoritis dari variabel independen dengan variabel dependen dan arti statistic (Gujarati, 2005).

2. Uji F

Uji $F$ untuk mengetahui apakah model regresi tersebut dapat digunakan untuk memprediksi atau dapat juga dikatakan variabel independen secara bersama-sama memiliki mempengaruhi terhadap variabel dependen.
3. Uji t

Uji t berguna untuk menguji signifikansi apakah variabel independen (X) berpengaruh secara nyata atau tidak. Untuk melakukan uji hipotesis biasanya digunakan uji t-test atau uji signifikan, level signifikansi dalam penelitian ini sebesar $5 \%(0,05)$.

\section{Hasil Penelitian dan Pembahasan}

Populasi dalam penelitian ini adalah perusahaan yang terdaftar pada Indeks Kompas 100 di Bursa Efek Indonesia selama tahun 2008 s.d. 2013.. Sampel pada penelitian ini dipilih dengan menggunakan metode purposive sampling yang mensyaratkan kriteria-kriteria tertentu, yaitu (1) Perusahaan terdaftar pada indeks Kompas 100 BEI periode 2008-2013; (2) Perusahaan secara konsisten menghasilkan laba selama periode 2008-2013; (3) Perusahaan secara konsisten membayarkan dividen kepada stockholders selama periode 2008-2013. Sehingga didapatkan 102 sampel observasi selama periode penelitian.

\subsection{Hasil Penelitian}

Tabel. 3 .

Statistik Deskriptif

\begin{tabular}{lrrrrr}
\hline & N & Minimum & Maximum & \multicolumn{1}{c}{ Mean } & Std. Deviation \\
\hline ERC & 102 & -.3573611 & .2756228 & -.029448962 & .1345546659 \\
BETA & 102 & .3981182 & 1.7966445 & 1.127325937 & .3035528685 \\
DAR & 102 & .13317921 & .92335856 & .5104866167 & .25450453970 \\
DPR & 102 & .0565 & 1.0006 & .402318 & .1886655 \\
EP & 102 & -1.3755836 & 2.6910022 & .687345498 & .6994812518 \\
\hline
\end{tabular}

Dari tabel 3 dapat diketahui bahwa earnings response coefficient (ERC) memiliki nilai minimum sebesar -0,357 (GGRM, 2013), nilai maksimum 0,275 (BBRI, 2008). Beta memiliki nilai minimum sebesar -0,398 (LSIP, 2013), nilai maksimum 1,797 (ANTM, 2009), Debt to asset ratio (DAR) memiliki nilai minimum sebesar 0,133 (INTP, 2011), nilai maksimum 0,923 (BBNI, 2008). Dividend payout ratio (DPR) memiliki nilai minimum sebesar 0,0565 (BMRI, 2009), nilai maksimum 1,000 (UNVR, 2011). Earnings persistence (EP) memiliki nilai minimum sebesar $-1,376$
(BDMN, 2009), nilai maksimum 2,691 (UNTR, 2008). 
Tabel 4

Hasil Koefisien Korelasi

\begin{tabular}{ccccc}
\hline Model & $\mathbf{R}$ & $\boldsymbol{R}$ Square & $\begin{array}{c}\text { Adjusted } \boldsymbol{R} \\
\text { Square }\end{array}$ & $\begin{array}{c}\text { Std. Error of the } \\
\text { Estimate }\end{array}$ \\
\hline 1 & $.311^{\mathrm{a}}$ & .097 & .060 & .130366843 \\
\hline
\end{tabular}

a. Predictors: (Constant), EP, DPR, BETA, DAR; b. Dependent Variable: ERC

Tabel 4 menunjukkan nilai koefisien korelasi (R) sebesar 0,311 lebih kecil dari 0,5 yang mengindikasikan hubungan antara variabel independen dengan varaibel dependen adalah lemah. Koefisien determinasi (Adjusted $R$-Square) model regresi dalam penelitian ini adalah 0,060. Artinya, besarnya variasi variabel dependen (BETA, DAR, DPR, dan EP) yang dapat dijelaskan oleh variasi variabel independen (ERC) adalah sebesar $6 \%$, sedangkan sisanya sebesar $94 \%$ dijelaskan oleh faktor-faktor lain yang dianggap tetap yang tidak dimasukkan ke dalam model regresi.

Tabel 5

Hasil Uji F ANOVA ${ }^{b}$

\begin{tabular}{llccccc}
\hline Model & $\begin{array}{c}\text { Sum of } \\
\text { Squares }\end{array}$ & df & $\begin{array}{c}\text { Mean } \\
\text { Square }\end{array}$ & F & Sig. \\
\hline $1 \quad$ Regression & .177 & 4 & .044 & 2.604 & $.041^{\mathrm{a}}$ \\
& $\begin{array}{l}\text { Residual } \\
\text { Total }\end{array}$ & 1.649 & 97 & .017 & & \\
& 1.826 & 101 & & & \\
\hline
\end{tabular}

a. Predictors: (Constant), EP, DPR, BETA, DAR

b. Dependent Variable: ERC

Berdasarkan diatas, F-hitung $(2,604)$ lebih besar dari pada F-tabel $(2,46)$ dengan signifikansi, yaitu $p$-value $(0,041)$ lebih kecil dari 0,05 . Hal ini mengindikasikan bahwa model regresi layak dan dapat digunakan untuk memprediksi atau variabel independen (BETA, DAR, DPR, dan EP) secara bersama-sama mempengaruhi variabel dependen (ERC).

Tabel. 6

Hasil Uji t

\begin{tabular}{lccccc}
\hline Model & $\begin{array}{c}\text { Unstandardized } \\
\text { Coefficients B }\end{array}$ & Std. Error & $\begin{array}{c}\text { Standardized } \\
\text { Coefficients } \\
\text { Beta }\end{array}$ & $\mathbf{t}$ & Sig. \\
\hline $1 \quad$ (Constant) & -.184 & .071 & & -2.544 & .013 \\
BETA & .028 & .045 & .062 & .616 & .539 \\
DAR & .126 & .053 & .239 & 2.368 & .020 \\
DPR & .187 & .073 & .264 & 2.573 & .012 \\
EP & -.021 & .019 & -.109 & -1.160 & .271 \\
\hline
\end{tabular}

a. Dependent Variable : ERC 
Berdasarkan tabel diatas, persamaan model regresi linear berganda dalam penelitian ini dapat dinyatakan sebagai berikut:

$\mathrm{ERC}=-\mathbf{0 , 1 8 4}+\mathbf{0 , 2 8} \mathrm{BETA}+\mathbf{0 , 1 2 6} \mathrm{DAR}+\mathbf{0 , 1 8 7} \mathrm{DPR}-\mathbf{0 , 0 2 1} \mathrm{EP}+\varepsilon$

Penjelasan mengenai pengaruh variabelvariabel independen terhadap variabel dependen secara parsial berdasarkan tabel 9 diuraikan sebagai berikut:

1. Risiko Sistematik (BETA)

Dari hasil uji $t$ diketahui bahwa nilai koefisien korelasi dari risiko sistematik (BETA) adalah sebesar 0,28. Hal tersebut berarti apabila nilai koefisien regresi variabel independen lainnya tetap (tidak berubah), maka perubahan 1 (satu) satuan BETA akan menaikkan ERC sebesar 0,28 satuan. Nilai t-hitung (0.616) lebih kecil daripada t-tabel (1.661) dan nilai signifikansi BETA $(0,539)$ lebih besar dari 0,05 maka Ha ditolak, yang berarti risiko sistematik (BETA) tidak berpengaruh secara signifikan terhadap earnings response coefficient (ERC).

2. Debt to asset ratio (DAR)

Dari hasil uji $\mathrm{t}$ diketahui bahwa nilai koefisien korelasi dari debt to asset ratio (DAR) adalah sebesar 0,126. Hal tersebut berarti apabila nilai koefisien regresi variabel independen lainnya tetap (tidak berubah), maka perubahan 1 (satu) satuan DAR akan menaikkan ERC sebesar 0,126 satuan. Nilai t-hitung $(2,368)$ lebih besar daripada t-tabel $(1,661)$ dan nilai signifikansi DAR $(0.020)$ lebih kecil dari 0,05 maka Ha diterima, yang berarti debt to asset ratio (DAR) berpengaruh secara signifikan terhadap earnings response coefficient (ERC).

3. Dividend payout ratio (DPR)

Dari hasil uji $\mathrm{t}$ diketahui bahwa nilai signifikansi dari dividend payout ratio (DPR) adalah sebesar 0,187. Hal tersebut berarti apabila nilai koefisien regresi variabel independen lainnya tetap (tidak berubah), maka perubahan 1 (satu) satuan DPR akan menaikkan ERC sebesar 0,187 satuan. Nilai t-hitung $(2,573)$ lebih besar daripada t-tabel $(1,661)$ dan nilai signifikansi DPR $(0.012)$ lebih kecil dari 0,05 maka Ha diterima, yang berarti dividend payout ratio (DPR) berpengaruh secara signifikan terhadap earnings response coefficient (ERC).

4. Earnings persistence (EP)

Dari hasil uji $t$ diketahui bahwa nilai signifikansi dari earnings persistence (EP) adalah sebesar $-0,021$. Hal tersebut berarti apabila nilai koefisien regresi variabel independen lainnya tetap (tidak berubah), maka perubahan 1 (satu) satuan EP akan menaikkan ERC sebesar -0,021 satuan. Nilai t-hitung $(-1,106)$ lebih kecil daripada t-tabel $(1,661)$ dan nilai signifikansi EP $(0,271)$ lebih besar dari 0,05 maka Ha ditolak, yang berarti earnings persistence (EP) tidak berpengaruh secara signifikan terhadap earnings response coefficient (ERC).

\subsection{Pembahasan}

\section{Pengaruh Risiko Sistematik (BETA) terhadap Earnings Response Coefficient (ERC)}

Hasil penelitian menunjukkan bahwa risiko sistematik (BETA) tidak berpengaruh terhadap earnings response coefficient (ERC). Hasil analisis regresi menunjukkan bahwa BETA memiliki hubungan yang positif terhadap ERC, semakin besar BETA maka semakin besar ERC. Dengan demikian menolak H1 yang menyatakan bahwa risiko sistematik berpengaruh negatif terhadap ERC. Hasil penelitian ini konsisten dengan hasil penelitian Chandarin (2003) yang didukung oleh hasil penelitian yang dilakukan oleh Harahap (2004), dan Jaswadi (2004) yang menyimpulkan bahwa risiko sistematik tidak memberikan pengaruh terhadap ERC.

Dalam penelitian ini salah satu kriteria pemilihan sampel adalah perusahaan yang terdaftar pada Indeks Kompas 100 BEI dan secara konsisten menghasilkan laba selama periode penelitian (2008-2013). Kinerja perusahaan yang efektif dalam menghasilkan laba mengakibatkan faktor risiko, termasuk risiko sistematis, tidak menjadi perhatian investor dalam pengambilan keputusan, sehingga risiko tidak berpengaruh terhadap koefisien respon laba (ERC). Hal ini terjadi karena investor melihat bahwa laba merupakan indikator earnings power dan return di masa mendatang (Mulyani et.al., 2007). Sebagian besar investor membeli saham untuk tujuan jangka pendek (capital gain), sehingga kurang memperhatikan beta sebagai resiko pasar ketika pengumuman laba.

Hasil penelitian ini konsisten dengan penelitian Palupi (2006) yang menyatakan bahwa kemungkinan investor Indonesia bukan merupakan tipe investor risk neutral, sehingga 
terhadap perusahaan dengan BETA kecil, investor cenderung tidak sensitif terhadap informasi laba. Sebaliknya pada perusahaan dengan BETA besar, guna menghindari kerugian maka setiap perubahan laba mendorong investor untuk memberikan reaksi.

\section{Pengaruh Debt to Asset Ratio (DAR) terhadap Earnings Response Coefficient (ERC)}

Hasil penelitian menunjukkan bahwa debt to asset ratio (DAR) secara signifikan berpengaruh terhadap earnings response coefficient (ERC). Analisis regresi menunjukkan bahwa DAR memiliki hubungan yang positif terhadap ERC, semakin besar DAR maka semakin besar ERC. Dengan demikian menolak $\mathrm{H} 2$ yang menyatakan bahwa DAR berepengaruh negatif terhadap ERC. Hasil penelitian ini menunjukkan leverage (DAR) berpengaruh positif terhadap ERC. Perusahaan dengan rasio leverage yang tinggi berarti bahwa perusahaan menggunakan hutang dan kewajiban lainnya untuk membiayai asset dan berisiko lebih tinggi dibandingkan perusahaan dengan leverage yang lebih rendah. Jika perusahaan dapat menggunakan aktiva tersebut pada tingkat pengembalian lebih tinggi dari biaya utang, maka akan meningkatkan laba. Disamping itu, komposisi hutang jangka panjang yang lebih besar dibandingkan hutang jangka pendek, dan digunakan untuk membiayai aset produktif, maka akan meningkatkan pengembalian pada modal.

Objek observasi pada penelitian ini mencakup seluruh industri dalam indeks Kompas 100 BEI yang termasuk kategori saham blue-chip dan well-managed yang berdasarkan frekuensi dan kapitalisasi pasar terbesar serta faktor fundamental seusai standar indutri dan pola perdagangan bursa. Sebanyak 53\% (lima puluh tiga persen) dari objek observasi memiliki nilai DAR di atas 0.50 , yang terdiri dari $50 \%$ (lima puluh persen) emiten sektor perbankan, dan sisanya merupakan emiten sektor non-perbankan. Dalam industri keuangan, utang merupakan salah satu bagian dari aktivitas utama yang dilakukan yaitu menghimpun dan menyalurkan dana. Utang merupakan salah satu sumber dana eksternal yang digunakan untuk menyalurkan dana kepada masyarakat. Semakin besar utang yang dimiliki maka semakin tinggi kemampuan untuk menyalurkan dana, dan hal ini akan dapat meningkatkan kemampuan perusahaan dalam menghasilkan laba (Cahyaningsih, 2009 dalam Imroatussolihah, 2013).

\section{Pengaruh Dividend Payout Ratio (DPR) terhadap Earnings Response Coefficient (ERC)}

Hasil penelitian menunjukkan bahwa dividend payout ratio (DPR) secara signifikan berpengaruh terhadap earnings response coefficient (ERC). Hasil analisis regresi menunjukkan bahwa DPR memiliki hubungan yang positif terhadap ERC, semakin besar DPR maka semakin besar ERC. Dengan demikian menerima $\mathrm{H} 3$ yang menyatakan bahwa DPR berpengaruh positif terhadap ERC. Hasil penelitian ini konsisten dengan penelitian Charest (1978) dalam Uyara dan Tuasikal (2002) menunjukkan bahwa return saham negatif ketika perusahaan mengurangi dividen dan return saham positif ketika perusahaan menaikkan dividen. Jensen (1986) memprediksi bahwa harga saham akan meningkat jika perusahaan membagikan kelebihan kas kepada pemegang saham. Pengujian terhadap deviden menunjukkan bahwa peningkatan pembayaran deviden dalam bentuk kas menghasilkan respon positif pada harga saham dalam jangka pendek. Kallapur (1994) menunjukkan bahwa reaksi harga saham yang diukur dengan earnings response coefficients berhubungan positif dengan rasio pembayaran dividen.

4. Pengaruh Earnings Persistence (EP) terhadap Earnings Response Coefficient (ERC)

Hasil penelitian menunjukkan bahwa earnings persistence (EP) tidak berpengaruh terhadap earnings response coefficient (ERC). Hasil analisis regresi menunjukkan bahwa EP memiliki hubungan yang negatif terhadap ERC, semakin besar EP maka semakin kecil ERC. Dengan demikian menolak H4 yang menyatakan bahwa earnings persistence (EP) berpengaruh positif terhadap ERC. Hasil penelitian ini sesuai dengan penelitian yang dilakukan oleh Ali dan Zahrowi (2002), yang menyatakan bahwa persistensi laba tidak berpengaruh terhadap ERC, adanya komponenkomponen transitory dalam laba menyebabkan laba kurang dapat dijadikan pengukur ERC. Banyaknya komponen transitory hanya akan 
berpengaruh terhadap laba saat ini akan tetapi tidak memengaruhi laba di masa datang. Komponen transitory sifatnya tidak berulang, artinya item transitory merupakan aktifitas yang tidak biasa. dilakukan dan tidak selalu terulang dimasa depan. Komponen transitory ini menyebabkan kurang relavannya laba digunakan untuk memprediksi kebijakan di masa datang.

Penelitian yang dilakukan Hapsari (2010) juga menunjukkan bahwa persistensi laba tidak berpengaruh terhadap ERC dengan penjelasan bahwa investor tidak merespon terhadap perubahan laba meskipun perusahaan telah menunjukkan persistensi laba yang positif untuk masa datang. Hal ini menunjukkan bahwa dalam menentukan investasinya investor tidak hanya menilai berdasarkan informasi laba, akan tetapi investor juga menilai informasi lain yang mungkin berpengaruh terhadap investasinya. Kesimpulan dari hasil penelitian di atas menunjukkan bahwa persistensi laba tidak selalu dapat dijadikan patokan dalam penentuan kebijakan investasi di masa depan karena dalam laba terdapat kemungkinan adanya item transitory yang tidak terjadi berulang sehingga tidak dapat menggambarkan laba dimasa depan, hal ini sejalan dengan pendapat Lev (1989) yang menyatakan bahwa meskipun laba digunakan oleh investor akan tetapikegunaan laba bagi investor sangat terbatas. Hasil penelitian ini konsisten dengan penelitian yang dilakukan oleh Harahap (2004) yang menyimpulkan bahwa persistensi laba tidak berpengaruh dan memiliki koefisien korelasi yang bernilai negatif terhadap ERC.

5. Pengaruh Resiko Sistematik (BETA), Debt to Asset Ratio (DAR), Dividend Payout Ratio (DPR), dan Earnings Persistence (EP) secara simultan terhadap Earnings Response Coefficient (ERC)

Hasil penelitian menunjukkan bahwa resiko sistematik (BETA), debt to asset ratio (DAR), dividend payout ratio (DPR), dan earnings persistence (EP) berpengaruh secara simultan terhadap earnings response coefficient (ERC). Dengan demikian menerima H5 yang menyatakan bahwa resiko sistematik (BETA), debt to asset ratio (DAR), dividend payout ratio (DPR), dan earnings persistence (EP) berpengaruh secara simultan terhadap earnings response coefficient (ERC). Hasil penelitian ini konsisten dengan hasil penelitian Imroatussolihah (2013) yang menyimpulkan risiko, leverage, peluang pertumbuhan, persistensi laba dan kualitas tanggung jawab sosial perusahaan secara simultan berpengaruh terhadap earnings response coefficient (ERC) pada perusahaan high profile.

\section{Simpulan, Keterbatasan dan Implikasi Hasil Penelitian}

Hasil pengujian dengan menggunakan regresi linear berganda membuktikan bahwa variabel risiko sistematik (beta) tidak berpengaruh terhadap earnings response coefficient (ERC). Variabel leverage (DAR) berpengaruh positif terhadap earnings response coefficient (ERC). Variabel dividend payout ratio (DPR) berpengaruh positif terhadap earnings response coefficient (ERC). Variabel earnings persistence (EP) tidak berpengaruh terhadap earnings response coefficient (ERC). Hasil pengujian secara simultan dengan menggunakan seluruh variabel independen, yaitu risiko sistematik (beta), leverage (DAR), dividend payout ratio (DPR), dan earnings persistence (EP) secara simultan berpengaruh terhadap earnings response coefficient (ERC).

Peneliti menyadari sepenuhnya bahwa penelitian yang telah dilakukan ini walaupun telah diupayakan semaksimal mungkin, akan tetapi masih mempunyai keterbatasan keterbatasan yang sulit untuk dihindari, antara lain :

1. Periode penelitian yang relatif singkat selama enam tahun dari tahun 2008 sampai dengan tahun 2013. Dengan pendeknya periode penelitian dan jumlah data yang terbatas, yaitu 19 perusahaan yang menjadi sampel sehingga jumlah data yang terkumpul sebanyak 114, sehingga hasilnya terlihat kurang optimal.

2. Penelitian ini hanya terbatas pada aspek keuangan saja yaitu risiko sistematik (beta), leverage (DAR), dividend payout ratio (DPR), dan earnings persistence (EP), tidak menggunakan aspek lain sehingga hasil penelitian tidak dapat menggambarkan situasi secara keseluruhan.

Saran yang dapat digunakan bagi pihak yang ingin melanjutkan penelitian ini adalah:

1. Penelitian selanjutnya dapat menambahkan faktor akuntansi lainnya seperti growth opportunities, ukuran (firm size), karateristik 
Industri, voluntary disclosure, corporate sosial responsibility (CSR), conservatism dan timeliness, serta faktor non-akuntansi lainnya seperti tingkat suku bunga, kurs, volume transaksi dan yield.

2. Jumlah sampel dapat diambil dengan periode pengamatan yang lebih lama dan menggunakan data-data yang literatur Pusat Referensi Pasar Modal Bursa Efek Indonesia, Indonesian Capital Market Library (ICaMEL), Indonesian Capital Market Directory (ICMD), dan situs BEI (www.idx.co.id).

\section{Daftar Pustaka}

Ansori, Mochkamad, Denica, 2010. Pengaruh Keputusan Investasi Keputusan Pendanaan Dan Kebijakan Dividen Terhadap Nilai Perusahaan Pada Perusahaan Yang Tergabung Dalam Jakarta Islamic Index Studi Pada Bursa Efek Indonesia ( BEI ). Jurnal Analisis Manajemen, Vol. 4 No. 2.

Arista, Desi, Astohar. 2012. Analisis FaktorFaktor yang Mempengaruhi Return Saham. Jurnal Ilmu Manajemen dan Akuntansi Terapan. Vol. 3 No. 1.

Belkaoui, A.R. 2004. Accounting Theory. Fifth edition. Hampshire: Cengage Learning EMEA.

Chandrarin, G. 2003. The Impact of Accounting Methods For Transaction Gains (Losses) on The Earnings Response Coefficient: The Indonesian Case. Jurnal Riset Akuntansi Indonesia. Vol. 6. No. 3. September: 217231.

Cheng, F. F., A. Nasir. 2010. Earning Response Coefficients and The Financial Risks of China Commercial Banks. International Review of Business Research Papers. Vol. 6, No. 3, Agustus: 178-188.

Diantimala, Yossi. 2008. Pengaruh Akuntansi Konservatif, Ukuran Perusahaan, dan Default Risk Terhadap Koefisien Respon Laba (ERC). Jurnal Telaah \& Riset Akuntansi. Vol. 1, No.1, Januari 2008: 102122.

Ghozali, Imam. 2013. Aplikasi analisis mutivariat dengan SPSS. Badan Penerbitan Universitas Diponegoro. Semarang.

Gujarati, D. 2005. Ekonometrika Dasar. Alih bahasa oleh Sumarno Zain. Jakarta: Erlangga.

Gumanti, Tatang Ary, Elok Sri Utami. 2002.
Bentuk Pasar Efisien dan Pengujiannya. Jurnal Akuntansi dan Keuangan. Vol. 4, No. $1: 54-68$.

Harahap, K. 2004. Asosiasi Antara Praktik Perataan Laba Dengan Koefisien Respon Laba. Makalah Simposium Nasional Akuntansi VII: 1164-1176.

Husnan, Suad. 2009. Dasar-dasar Teori Portofolio dan Analisis Sekuritas. Edisi 4: Revisi 2. Yogyakarta : UPP STIM YKPN.

Imroatussolihah, Eli. 2013. Pengaruh Resiko, Leverage, Peluang Pertumbuhan, Persistensi Laba, dan Kualitas Tanggung Jawab Sosial Perusahaan Terhadap Earnings Response Coefficient pada Perusahaan High Profile. Jurnal Ilmu Manajemen. Vol. 1, No. 1: 7587.

Jogiyanto H. 2010. Teori Portofolio dan Analisis Investasi. Edisi 7. Yogyakarta: BPFE Yogyakarta.

Jogiyanto H. 2010. Metodologi Penelitian Bisnis: Salah Kaprah dan PengalamanPengalaman. Edisi 6. Yogyakarta: BPFE Yogyakarta.

Jaswadi. 2004. Dampak Earning Reporting Lags terhadap Koefisien Respon Laba. Jurnal Riset Akuntansi Indonesia, Vol. 7, No. 3: 295-315.

La Porta, R., F. Lopez-de-Silanes, A. Shleifer and R. Vishny. 2002. Investor Protection and Corporate Valuation. Journal of Finance. Vol. LVII No.3: 1147-1170.

Mulyani, Sri., Nur F. Asyik dan Andayani. 2007. Faktor-Faktor yang Mempengaruhi Earnings Response Coefficient pada Perusahaan yang Terdaftar di Bursa Efek Jakarta. Jurnal Akuntansi dan Auditing Indonesia, Vol. 11, No.1: 35-45.

Murwaningsari, Etty. 2008. Pengujian Simultan: Beberapa Faktor yang Mempengaruhi Earnings Response Coeficient (ERC). Simposium Nasional Akuntansi XI.

Mayangsari. 2004. Bukti Empiris Pengaruh Spesialisasi Industri Auditor Terhadap Earnings Response Coefficient. Jurnal Riset Akuntansi Indonesia, Vol. 7. No. 2, Mei, Hal: 154-178.

Palupi, Margaretta Jati. 2006. Analisis FaktorFaktor yang Mempengaruhi Koefisien Respon Laba: Bukti Empiris pada Bursa Efek Jakarta. Jurnal Ekubank, Vol. 3: 9-25.

Scott, W. R. 2012. Financial Accounting Theory. 6th Ed. Ontairo: Prentice Hall Inc.

Suaryana. 2004. Pengaruh Komite Audit 
Terhadap Koefisien Respon Laba. Tesis, Universitas Gajah Mada. Yogyakarta.

Subalno. 2009. Analisis Pengaruh Faktor Fundamental dan Kondisi Ekonomi Terhadap Return Saham (Study Kasus pada Perusahaan Otomotif dan Komponen yang Listed di Bursa Efek Indonesia Periode 2003-2007). Tesis. Universitas Diponegoro. Semarang.

Uyara, Ali Sani dan A.Tuasikal. 2002. Moderasi Aliran Kas Bebas Terhadap Hubungan Rasio Pembayaran Dividen dan Pengeluaran Modal dengan Earnings Response Coefficients. Simposium Nasional Akuntansi V: 16-26. 